\title{
Effects of fetal bovine serum and estrus buffalo serum on maturation of buffalo (Bubalus bubalis) oocytes in vitro
}

\author{
Gopal Puri, S. S. Chaudhary, V. K. Singh and A. K. Sharma \\ Department of Veterinary Physiology \& Biochemistry, Vanbandhu College of Veterinary Science \& Animal Husbandry, \\ Navsari Agricultural University, Navsari - 396 450, Gujarat, India. \\ Corresponding author: Gopal Puri, e-mail: drgopalpuri@gmail.com, SSC: sandhyachaudhary@live.com, \\ VKS: drvksingh1981@gmail.com, AKS: drarunvet@gmail.com \\ Received: 04-09-2014, Revised: 22-12-2014, Accepted: 30-12-2014, Published online: 09-02-2015
}

doi: 10.14202/vetworld.2015.143-146. How to cite this article: Puri G, Chaudhary SS, Singh VK, Sharma AK (2015) Effects of fetal bovine serum and estrus buffalo serum on maturation of buffalo (Bubalus bubalis) oocytes in vitro, Veterinary World, 8(2): 143-146.

\begin{abstract}
Aim: The aim was to assess the effects of fetal bovine serum (FBS) and estrus buffalo serum (EBS) on in vitro maturation rate of oocytes in buffalo.

Materials and Methods: Maturation rate of oocytes was assessed in two maturation media supplemented with $20 \%$ FBS and EBS. Oocytes maturation rate was evaluated on the basis of cumulus cell expansion and extrusion of polar body after $24 \mathrm{~h}$ of in vitro culture in $\mathrm{CO}_{2}$ incubator.
\end{abstract}

Results: The average percentage of in vitro matured oocytes in FBS was $83.80 \%$, and EBS was $77.45 \%$, respectively. The results revealed a significant $(\mathrm{p}<0.05)$ increase in maturation rate of oocytes in FBS than EBS.

Conclusion: Buffalo oocytes were better in vitro matured in FBS than EBS.

Keywords: buffalo oocytes, estrus buffalo serum, fetal bovine serum, in vitro maturation.

\section{Introduction}

In vitro cell or tissue cultures play an important role for research in science and industry. Fetal bovine serum (FBS) is a common supplement to in vitro and ex vivo cell, tissue and organ cultures [1]. FBS contains essential components hormones, vitamins, transport proteins, and attachment, spreading and growth factors [2]. It is estimated that about 500,000 L of serum are produced on an annual basis, for this purpose more than 1,000,000 bovine fetuses have to be harvested annually for obtaining fetal calf serum [3]. Methods to reduce the requirements for FBS in culture media as well as alternative animal serum substitutions were described earlier [4]. The removal of serum from the cell culture medium or the replacement with other complex biological fluids and extracts initiates multifarious variations in the interactive nature of the cell culture system.

In vitro maturation $(I V M)$ and in vitro fertilization $(I V F)$ procedures performed on oocytes obtained from slaughter-house derived ovaries have recently provided a practical means for producing large number of bovine zygotes at low cost for research and commercial settings [5]. The oocytes maturation is a crucial step for the generation of quality oocytes capable of being fertilized and undergoing normal embryonic development into blastocyst after IVF [6]. There have been reports to enhance early development of in vitro produced embryos in domestic animals by

Copyright: The authors. This article is an open access article licensed under the terms of the Creative Commons Attributin License (http:// creative commons.org/licenses/by/2.0) which permits unrestricted use, distribution and reproduction in any medium, provided the work is properly cited. addition of sera, hormones, and somatic cells [7]. Supplementation of serum in media had a biphasic favorable effect on maturation. The serum contains a number of known growth factors that have an important role in the regulation of oocyte maturation, particularly via cumulus cells it also prevents the hardening of the zona pellucida; moreover, the beneficial action of serum may be due to its anti-oxidant properties [8].

The present experiment was designed to assess the effects of FBS and estrus buffalo serum (EBS) on $I V M$ rate of oocytes in buffalo.

\section{Materials and Methods}

\section{Collection of oocytes}

Buffalo ovaries of unknown reproductive status were collected from local slaughter house and carried to the laboratory in normal saline solution $(0.85 \%$ $\mathrm{NaCl})$ fortified with gentamicin $(50 \mu \mathrm{g} / \mathrm{ml})$ in a thermo flask at $37-38^{\circ} \mathrm{C}$ within $2 \mathrm{~h}$ of slaughter. In the laboratory, extraneous tissue was removed, and ovaries were thoroughly washed with $70 \%$ ethanol followed by three rinses in phosphate buffer saline solution.

\section{Grading of oocytes}

Oocytes were aspirated from all the visible nonatretic surface follicles of the ovary by using $5 \mathrm{ml}$ sterile syringe fitted with $18 \mathrm{G}$ needle containing oocytes collection medium after final washing. The searching of oocytes was carried out in oocytes collection media under stereo zoom microscope. Cumulus oocytes complexes (COCs) were recovered by scoring method [9]. Oocytes possessing a full cumulus mass, unfragmented cytoplasm, and intact zona were selected for further processing. The COCs were evaluated and 
graded by the methods [10]. Good and excellent quality oocytes having more than 3-5 cumulus cell layers were cultured in $50 \mu \mathrm{l}$ droplets (20-25 oocytes/droplet) of maturation media in $35 \mathrm{~mm}$ sterile petri dish.

\section{IVM of oocytes}

The excellent ( $>5$ layers) and good ( $>3$ layers) quality of COCs were selected for IVM. The selected COCs were divided randomly into two groups for maturation in culture: (i) IVM medium (TCM-199 with HEPES media, $10 \%$ buffalo follicular fluid, $0.5 \mu \mathrm{g} /$ $\mathrm{ml}$ follicle-stimulating hormone, $10 \mu \mathrm{g} / \mathrm{ml}$ luteinizing hormone, $0.5 \mu \mathrm{g} / \mathrm{ml}$ estradiol) supplemented with $20 \%$ FBS (FBS; Sigma, USA); (ii) IVM medium supplemented with $20 \%$ EBS obtained from estrus buffalo. Selected COCs were cultured in sterile tissue culture petri dish (35 mm $\times 35 \mathrm{~mm}$; Axiva) containing $100 \mu \mathrm{l}$ of $I V M$ medium at $38.5^{\circ} \mathrm{C}$ in an atmosphere of $5 \% \mathrm{CO}_{2}$ and $95 \%$ air with high humidity in $\mathrm{CO}_{2}$ incubator for $24 \mathrm{~h}$. Following $24 \mathrm{~h}$ of culture, matured oocytes in both the drops were observed on the basis of cumulus cell expansion, extrusion of first polar body and metaphase II plate were indicators of oocyte maturation and considered as matured oocytes.

\section{Results}

The effect of supplementation of $20 \%$ FBS and EBS in maturation media on the maturation rate of buffalo oocytes is given in Table- 1 and Figure-1. The results revealed a significant $(p<0.05)$ increase in maturation rate when the maturation media was supplemented with FBS than in EBS supplemented media. The percentage of $I V M$ of oocytes in TCM-199 with supplementation of $20 \%$ FBS was significantly higher $(83.80 \%)$ than in EBS (77.45\%). IVM of buffalo oocytes was significantly $(p<0.05)$ better in FBS as compared to EBS, which might be due to the effect of growth factors, nutrients and anti-oxidant present in FBS. Thus, FBS as a supplement in maturation media increases the IVM rate of bovine oocytes better than EBS.

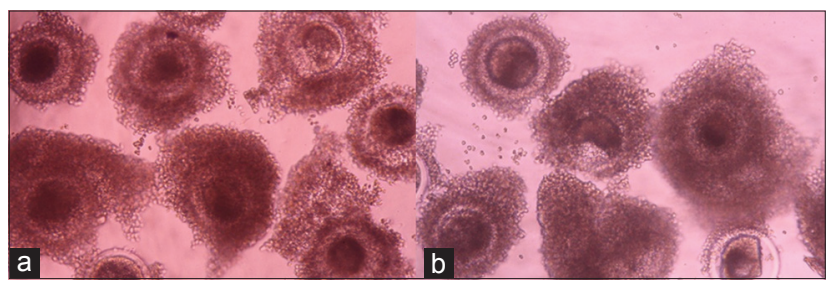

Figure-1: In vitro maturation of buffalo oocytes in fetal bovine serum (FBS) and estrus buffalo serum (EBS) supplemented maturation media, (a) In vitro maturation of oocytes in FBS $(\times 20)$, (b) in vitro maturation of oocytes in $\operatorname{EBS}(\times 20)$.

\section{Discussion}

Immature bovine oocytes cultured in standard maturation medium, they resume the first meiotic division which is essential for oocytes to achieve full developmental competence for fertilization. The alteration of basic maturation conditions can affect oocyte competence significantly as reflected by the morula and blastocyst yield after IVF [11]. A number of ultrastructural and molecular changes occurring during oocytes development are linked to the developmental competence of the gamete [12].

In most studies on IVM of animal oocytes, the basic medium is supplemented with different kinds of sera [13]. Serum is commonly used as a supplement to cell culture media [14]. FBS has been considered as a universal growth media for cell culture. It can be used as culture additive for the stimulation of cellular proliferation, and it contains essential components such as hormones, vitamins, transport proteins and attachment, spreading and growth factors [2]. The serum contains a number of known growth factors that have an important role in the regulation of oocyte maturation, particularly via cumulus cells it also prevents the hardening of the zona pellucida. Moreover, beneficial action of serum may be due to its anti-oxidant properties [8]. The major functions of serum are to provide hormonal factors which stimulate cell growth and proliferation, promotes differentiated functions, transport proteins carrying hormones, minerals trace elements, lipids, attachment and spreading factors and stabilizing and detoxifying factors [14]. A favorable effect of estrus cow serum when added to the maturation medium promotes the rupture of germinal vesicle and induces oocytes maturation [15]. Basic media supplemented with, estrus sheep serum and estrus goat serum supported better rates of IVM, IVF and embryo development of ovine oocyte [16]. Hence, supplementation of media with serum had a biphasic favorable effect on maturation. The beneficial effects of serum for oocyte maturation may also be via cumulus cells or directly on the oocytes. Supplementation of buffalo follicular fluid and FBS at different fraction obtained by ultracentrifugation, are effective maturation medium, as they promoted the development of high quality matured bovine oocytes [17]. FBS can be supplemented in $I V M$ and $I V F$ media to achieve better maturation and cleavage [18]. Oocytes for IVM are typically selected supported their cumulus investment and homogeneity of cytoplasm. The gap junctions between oocyte and cumulus cells were needed for the transport of growth factors and hormones

Table-1: In vitro maturation rate of buffalo oocytes in FBS and EBS supplemented maturation medium.

\begin{tabular}{|c|c|c|c|c|c|c|}
\hline \multirow{2}{*}{$\begin{array}{l}\text { Total number } \\
\text { of ovary used }\end{array}$} & \multirow{2}{*}{$\begin{array}{c}\text { Oocyte/ } \\
\text { ovary }\end{array}$} & \multirow{2}{*}{$\begin{array}{l}\text { Culturable } \\
\text { oocytes }\end{array}$} & \multicolumn{2}{|c|}{ Number of oocytes cultured $(20 \%)$} & \multicolumn{2}{|c|}{ Matured oocytes (\%) } \\
\hline & & & FBS & EBS & FBS & EBS \\
\hline 266 & 1.16 & 207 & 105 & 102 & $88(83.80)$ & $79(77.45)$ \\
\hline
\end{tabular}

FBS $=$ Fetal bovine serum, EBS $=$ Estrus buffalo serum 
necessary for normal maturation and developmental competence $[19,20]$. Various protein supplements are essential for cellular modifications (specialization of cell) and growth in various living systems that support the interactions with cellular proliferation and MAPK networks [21]. The addition of different thiol compounds (cystine, cysteine, cysteamine, glutathione [GSH], $\beta$ mercaepthanol) to the $I V M$ media improve embryo development, increases intra-cytoplasmic GSH concentration and protects cells from culture oxidative stress $[22,23]$. The effect of supplementation of synthetic oviduct fluid with glucose and vitamins has been experimented [24] during the first step of the in vitro culture of ovine zygotes. Addition of hydrolyzed plant proteins have anti-apoptotic properties [25] and contains numerous free amino-acids, short oligopeptides, some vitamins and carbohydrates, which may cumulatively be responsible for improved embryo production [26]. Supplementation of protein additives informs ovine amniotic fluid, FBS or sheep serum to culture media are more efficacious for IVM of sheep oocytes [27]. In contrary, a better cleavage rate was achieved with the static culture method supplemented with EBS, as compared to static methods with FCS and flux culture methods with either EBS or FCS in buffalo and IVM of oocyte with static culture containing EBS would be a potential method to reduce the cost of laboratory produced buffalo embryos [28]. Addition of hormone combinations with FBS to culture media could significantly improve the $I V M$ of sheep oocytes [29]. In the present study, IVM rate of buffalo oocytes was enhanced in FBS supplemented maturation medium while in EBS, maturation rate was slower.

\section{Conclusion}

The maturation rate of oocytes was higher in FBS than EBS, which might be due to the effect of growth factors, nutrients and anti-oxidant present in FBS and has also been observed that the anti-oxidant play important role in the maturation of oocytes as they are the scavenger of free radicals. It can thus be concluded that FBS is better than EBS for IVM of buffalo oocytes, although EBS might be used as serum substitute for maturation of oocytes but rate was slower instead of FBS.

\section{Authors' Contributions}

GP along with SSC designed the experiment and conducted the experiment with the help of AKS and VKS. GP analyzing the data and preparing the manuscript. GP, SSC, VKS and AKS reviewed the manuscript. All authors read and approved the final manuscript

\section{Acknowledgments}

The authors are grateful to the Dean, College of Veterinary Sciences and A.H., Navsari Agricultural University, Navsari for providing the necessary funds and facilities to conduct this research experiment.

\section{Competing Interests}

The authors declare that they have no competing interests.

\section{References}

1. van der Valk, J., Mellor, D., Brands, R., Fischer, R., Gruber, F., Gstraunthaler, G., Hellebrekers, L., Hyllner, J., Jonker, F.H., Prieto, P., Thalen, M. and Baumans, V. (2004) The humane collection of fetal bovine serum and possibilities for serum-free cell and tissue culture. Toxicol. In Vitro, 18(1): 1-12.

2. Maurer, H. (1986) Towards chemically-defined, serum-free media for mammalian cell culture. In: Freshney, R. editors. Animal Cell Culture: A Practical Approach. IRL Press, Oxford.

3. Jochems, C.E., van der Valk, J.B., Stafleu, F.R. and Baumans, V. (2002) The use of fetal bovine serum: Ethical or scientific problem. Altern. Lab. Anim., 30(2): 219-227.

4. Jayme, D.W., Epstein, D.A. and Conrad, D.R. (1988) Fetal bovine serum alternatives. Nature, 334: 547-548.

5. Hansen, P.J. (2006) Realizing the promise of IVF in cattle-an overview. Theriogenology, 65(1): 119-125.

6. Wang, W.H. (1997) Effect of oocytes maturation media on development of pig embryos by in vitro fertilization. J. Reprod. Fertil., 111: 101-108.

7. Pawshe, C.H., Palanisamy, A., Taneja, M., Jain, S.K. and Totey, S.M. (1996) Comparison of various maturation treatments on in vitro maturation of goat oocytes and their early embryonic development and cell numbers. Theriogenology, 46(6): 971-981.

8. Mahmoud, G.M. and Nawito, M.F. (2003) Cytogenetic evaluation of in vitro matured buffalo oocytes in different culture condition. Egypt J. Vet. Sci., 37: 105-116.

9. Samad, H.A., Khan, I.Q., Rehman, N.U. and Ahmad, N. (1998) The recovery, in vitro maturation and fertilization of Nili-Ravi buffalo follicular oocytes. Asian Aust. J. Anim. Sci., 11: 491-497.

10. Kobayashi, K., Yamashita, S. and Hoshi, H. (1994) Influence of epidermal growth factor and transforming growth factor- $\alpha$ on in vitro maturation of cumulus cell-enclosed bovine oocytes in a defined medium. J. Reprod. Fertil., 100(2): 349-446.

11. Sirard, M.A. and Conean, K. (2006) In vitro maturation and embryo production in cattle. Methods Mol. Biol., 348: $35-42$.

12. Hyttel, P. (1997) Bovine cumulus oocyte disconnection in vitro. Anat. Embryol., 176(1): 41-44.

13. Hegab, A.O., Montasser, A.E., Hammam, A.M., Abu El-Naga, E.M.A. and Zaabel, S.M. (2009) Improving in vitro maturation and cleavage rates of buffalo oocytes. Anim. Reprod., 6(2): 416-421.

14. Gstraunthaler, G. (2003) Alternatives to the use of fetal bovine serum: Serum-free cell culture. ALTEX, 20(4): 275-281.

15. Kito, S. and Bavister, B.D. (1997) Gonadotropins, serum and amino acids after nuclear maturation, cumulus expansion, and oocyte morphology in hamster cumulus-oocyte complexes in vitro. Biol. Reprod., 56(5): 1281-1289.

16. Karami Shabankareh, H., Sarsaifi, K. and Mehrannia, T. (2011) In vitro maturation of ovine oocytes using different maturation media: Effect of human menopausal serum. J. Assist. Reprod. Genet., 28(6): 531-537.

17. Momozawa, K. and Fukuda, Y. (2011) Effects of fractions of bovine follicular fluid and fetal bovine serum as supplements to maturation medium on in vitro development of in vitro fertilized bovine embryos. J. Mamm. Ova Res., 28(1): 68-74.

18. Sreenivas, D., Kaladhar, D.S., Yarla, N.S., Thomas, V.M. and Palnisamy, A. (2013) Effect of protein supplementation on in vitro maturation of sheep oocytes and in vitro culture of preimplantation with $\alpha$-tocopherol supplementation in 
CR1aa medium on sheep embryos to the blastocyst stage. J. Allergy. Ther., 4: 133.

19. Buccione, R., Schroeder, A.C. and Eppig, J.J. (1990) Interactions between somatic cells and germ cells throughout mammalian oogenesis. Biol. Reprod., 43(4): 543-547.

20. Mori, T., Amano, T. and Shimizu, H. (2000) Roles of gap junctional communication of cumulus cells in cytoplasmic maturation of porcine oocytes cultured in vitro. Biol. Reprod., 62(4): 913-919.

21. Sreenivas D., Kaladhar, D.S., Samy, A.P. and Kumar, R.S. (2012) Understanding mechanism of in vitro maturation, fertilization and culture of sheep embryoes through in silico analysis. Bioinformation, 8(21): 1030-1034.

22. Paramio, M.T. (2010) In vivo and in vitro embryo production in goats. Small Rumin. Res., 89: 144-148.

23. Wani, A.R., Khan, M.Z., Sofi, K.A., Lone, F.A. and Malik, A.A., Bhat, F.A. (2012) Effect of cysteamine and epidermal growth factor (EGF) supplementation in maturation medium on in vitro maturation, fertilization and culturing of embryos in sheep. Small Rumin. Res., 106: 160-164.

24. Karami, S.H. and Akhondi, M. (2012) Effect of glucose levels and MEM vitamins during the first step of IVC in synthetic oviduct fluid medium on in vitro development of ovine zygotes. Small Rumin. Res., 106: 54-58.

25. Kaladhar, D.S.V.G., Chandra, S.P., Nageswara, R.P.V., Krishna, C.A. and Govinda, R.D., Rao, V., Reddy, R., Kumar, V., Kumar, V., Reddy, B. (2012) Protein interaction networks in metalloproteins and docking approaches of metallic compounds with TIMP and MMP in control of MAPK pathway. Lett. Drug Des. Discov., 10: 49-55.

26. Grad, I., Gajda, B. and Smorag, Z. (2010) Effect of plant protein supplementation on in vitro development of porcine embryos. Anim. Sci. Pap. Rep., 28: 271-279.

27. Farag, I.M., Girgis, S.M., Hassan, N.H.A., Khalil, W.K.B., Sakr, A.A.M. and Ali, N.I. (2010) Effect of protein additives on in vitro maturation of Egyptian sheep oocytes with reference to seasonal variation effects on yield and quality of oocytes. J. Am. Sci., 6(10): 588-599.

28. Abid, M., Anwar, M., Sayed, M., Hassan, A., Muhammad, A., Saqlan, N.S.M. (2011) In vitro maturation and fertilization of buffalo oocytes: The effect of recovery and maturation methods. Turk. J. Vet. Anim. Sci., 35(6): 381-386.

29. Farag, I.M., Girgis, S.M., Khalil, W.K.B., Hassan, N.H.A., Sakr, A.A.M., Abd Allah, S.M. and Ali, N.I. (2009) Effect of hormones, culture media and oocyte quality on in vitro maturation of Egyptian Sheep oocytes. J. Appl. Biosci., 24: $1520-1534$.

\section{$* * * * * * * *$}

